\title{
CUTTING DISTANCE AS FACTOR TO EVALUATE THE QUALITY OF WOOD MACHINED SURFACES: A PRELIMINARY STUDY
}

\author{
Alfredo Aguilera ${ }^{1}$, Aldo Rolleri ${ }^{1, \star}$, Francisco Burgos $^{1}$
}

\begin{abstract}
Surface quality of solid wood products is an important subject of study since it influences further manufacturing processes, such as finishing or strength of adhesive joint. In this study, the surface quality of the machined surfaces was evaluated through the cutting distance, which is defined as the accumulated linear meters of wood processed by a cutting tool. The roughness $\left(\mathrm{R}_{\mathrm{z}}\right)$ and wetting (contact angle) behaviour on wood machined surfaces have been assessed each 2000 meters respectively, from 0 to 10000 meters. In Pinus radiata samples, machined using a three hydro centred mounting cutter-heads of 6 knives HSS (High Speed Steel) $6 \% \mathrm{~W}$ (Wolfram) and a rake angle of $15^{\circ}$ each, similar contact angles were found associated to different values of $R_{z}$ through the cutting distance. This study verifies that a wide spectrum of cutting distance allows an accurate evaluation of roughness and wettability behaviour surface characteristics.
\end{abstract}

Keywords: Cutting distance, roughness, surface quality, wettability, wood.

\section{INTRODUCTION}

Surface quality of solid wood products is one of the most important properties influencing further manufacturing processes such as finishing or strength of adhesive joint (Kilic 2006, Aguilera and Muñoz 2011). Moreover, determination of surface quality is a complex process depending on the heterogeneous structure of the wood and machining conditions (Malkocoglu 2007). Usually the surface of manufactured wood elements results from a partitioning process achieved through one or more consecutive cutting and smoothing steps (Thoma et al. 2015). Roughness and wetting are important surface characteristics that are normally used to assess surface quality. Follrich (2010), indicates that rough surfaces may promote starving of the adhesive, as well as facilitate the mechanical interlocking of the adhesive. Baysal et al. (2014) and De-Moura et al. (2014), coincide that surface roughness of wood products depends on many factors such as raw material, tools and machine conditions. In wood machining, the combination of forces arising from a given tool geometry, controls the type of chips that are formed and, therefore, the quality of the machined surface (River et al. 1991). When cuttingtool angles change, for example, on a dull edge tool, these changes affect the surface characteristics. Itaya and Tsuchiya (2003), cited by Aknouche et al. (2009), concluded that the direct consequence of the cutting edge wear is the gradual loss of its ability to cut the machined material. These conditions also result in a poor wood surface quality. To evaluate the wear effect of the cutting tools on the surface characteristics, artificial wear has been induced by the accumulated cutting distance. The cutting distance is defined as the accumulated linear meters of wood processed by the cutting tool. Keturakis and Juodeikienè (2007), modelled artificially the cutting edges of the knives and found that a decrease on tool edge blunt radius during milling decreases the surface roughness of birch wood. Gilewicz et al. (2010), evaluated the effect of knife wear caused by the cutting distances of 1000, 3000 and 6000 meters on the surface characteristics and found an almost linear increase of $\mathrm{R}_{\mathrm{z}}$ together with the tool wear. Therefore, the main objective of this study was to determine the roughness and wettability behaviour in function of cutting distance, to assess the surface quality during Pinus radiata wood machining.

\footnotetext{
${ }^{1}$ Laboratorio de Productos Forestales, Instituto de Bosques y Sociedad, Facultad de Ciencias Forestales y Recursos Naturales. Universidad Austral de Chile. Valdivia, Chile.

•Corresponding author: arolleri@uach.cl

Received: 26.02.2015 Accepted: 01.10.2015
} 


\section{MATERIALS AND METHODS}

In this study Pinus radiata D. Don samples, Table 1 , with a mean density of $0,47 \mathrm{~g} / \mathrm{cm}^{3}$ (NCh176/1) and a mean EMC of 10,9 \% (NCh176/2) according to Chilean standard, were machined using a single-spindle shaper machine with variable cutting speed and feed, with three hydro centered mounting cutter-heads of 6 knives (High Speed Steel $6 \%$ Wolfram) and a rake angle of $15^{\circ}$ each.

Table 1. Experimental conditions

\begin{tabular}{lccc}
\hline Factors & Wood & Tool Wear & $\begin{array}{c}\text { Surface quality } \\
\text { measuring }\end{array}$ \\
\hline Density & $0,47 \mathrm{~g} / \mathrm{cm}^{3}$ & & \\
Equilibrium Moisture & $10,9 \%$ & & \\
content (EMC) & $15^{\circ}$ & $15^{\circ}$ \\
Rake angle & $1 \mathrm{~mm}$ & $1 \mathrm{~mm}$ \\
Cutting depth & $26 \mathrm{~m} / \mathrm{min}$ & $38 \mathrm{~m} / \mathrm{min}$ \\
Feed speed $\left(\mathrm{V}_{\mathrm{f}}\right)$ & $50 \mathrm{~m} / \mathrm{s}$ & 44 and $56 \mathrm{~m} / \mathrm{s}$ \\
Cutting speed $\left(\mathrm{V}_{\mathrm{c}}\right)$ & 0 to 10000 meters & each $2000 \mathrm{~meters}$ \\
Cutting distance & & \\
\hline
\end{tabular}

To accumulate wear on cutting tool, Pinus radiata wood samples were processed under specific machining conditions from 0 to 10000 meters of cutting distance. Furthermore, to evaluate the effect of cutting distance on the behavior of roughness and wettability, each 2000 meters, the single-spindle shaper machine was set up with specific machining conditions to process samples previously conditioned at $20^{\circ} \mathrm{C} / 30 \% \mathrm{HR}$ (Table 1). Measuring the surface quality consider three replicates and six repetition conditions for each cutting speed $\left(\mathrm{V}_{c}\right) 44 \mathrm{~m} / \mathrm{s}$ and $56 \mathrm{~m} / \mathrm{s}$ ). To avoid the effect of environment, within an hour at most the machined surfaces were set to measure the surface characteristics. For roughness, six values of mean peak-to-valley height $\left(\mathrm{R}_{\mathrm{z}}\right.$ ) parameter by ISO 4287 (1997) standard were collected using a Mitutoyo SJ-201 apparatus and they were always measured in the same direction of the machining. Once the roughness measurements were completed, the same wood samples and position for surface roughness measuring were used to assess wood machined wettability. There, contact angle of drop (distilled water) was measured dynamically during 15 seconds, using a Krüss device model DSA25, the angle used on this study was to the second 15 . On the other hand, in order to control the amount of accumulated wear, each 2000 meters of cutting distance the recession of the cutting edge was measured from an image of a knife mold made of silicone, using a Canon EOS Rebel T3 12,2 pixels digital camera with a help of a Stereomicroscope Zeiss Stemi DV4 and free software (Figure 1).

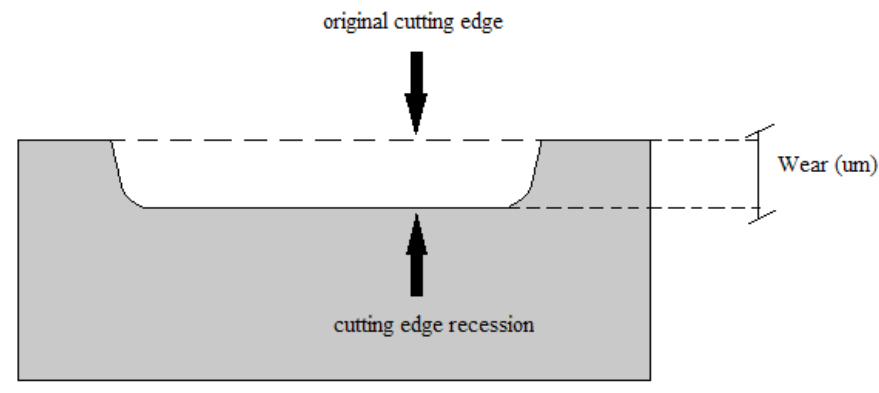

Figure 1. Schematic measuring principle used to assess the knives wear through the cutting distances. 
The statistical analysis of the data was carried out using the R free statistical software.

\section{RESULTS AND DISCUSSION}

In this work, the behaviour of surface properties, roughness and wettability, were assessed in function of the cutting distance. The roughness $\mathrm{R}_{7}$ through the cutting distance shows similar values among the cutting speed considered in this study, $44 \mathrm{~m} / \mathrm{s}$ and $56 \mathrm{~m} / \mathrm{s}$. On the other hand, analysis of variance was carried out on the basis of two factors (i.e. cutting distance and cutting speed). Table 2, shows that cutting distance is the most significant factor of variation to roughness $R_{z}$, in comparison with the cutting speed $V_{c}$ effect, which is lower.

Table 2. Analysis of variance related to the considered factor (cutting distance and cutting speed) on surface characteristics of machined Pinus radiata wood.

\begin{tabular}{cccccc}
\hline Roughness & Df & Sum Sq & Mean Sq & F value & $\operatorname{Pr}(>\mathrm{F})$ \\
\hline $\mathrm{d}$ & 1 & 788 & 788,4 & 39,289 & $2 \mathrm{e}-09 * * *$ \\
$\mathrm{~V}_{\mathrm{c}}$ & 1 & 22 & 22,2 & 1,106 & 0,294 \\
Residuals & 213 & 4274 & 20,1 & & \\
\hline Contact angle & $\mathrm{Df}$ & Sum Sq & Mean Sq & $\mathrm{F}$ value & $\operatorname{Pr}(>\mathrm{F})$ \\
\hline $\mathrm{d}$ & 1 & 2621 & 2621 & 29,13 & $1,79 \mathrm{e}-07 * * *$ \\
$\mathrm{~V}_{\mathrm{c}}$ & 1 & 3619 & 3619 & 40,23 & $1,33 \mathrm{e}-09 * * *$ \\
Residuals & 213 & 19162 & 90 & & \\
\hline
\end{tabular}

In case of contact angle, the analysis of variance shows that the wetting of machined surfaces it is more affected by the cutting speed than cutting distance. Nevertheless, both cutting distance (d) and cutting speed $\left(\mathrm{V}_{\mathrm{c}}\right)$ are significant factors of variation. The correlations between cutting distance and roughness, as well cutting distance with wettability (contact angle) of machined surfaces, were evaluated in order to reveal the presence of possible relationships between them. Pearson correlation indicate that data were significantly out of the regression line. In fact, $\mathrm{R}^{2}$ for roughness $\left(\mathrm{R}_{\mathrm{z}}\right)$ was 0,39 and 0,32 for contact angle (CA). For this reason, quadratic equation that best fits the data was selected. Trend lines that best fit the data of roughness and wettability are presented in figures 2 and 3 .

Figure 2 shows how the surface roughness of Pinus radiata wood varies throughout the cutting distance. In general, for both cutting speed used $(44 \mathrm{~m} / \mathrm{s}$ and $56 \mathrm{~m} / \mathrm{s})$ the roughness parameter $R_{z}$ increased until near 6000 meters of cutting distance. Gilewicz et al. (2010), also studied the effect of milling distance (from 0 to 6000 meters) and found that the $\mathrm{R}_{\mathrm{z}}$ parameter of wood surfaces increases with the tool wear when using an uncoated cutting tool. However, in this study, over 7000 meters $R_{z}$ values begin to diminish as the cutting distance increase. On the other hand, the surfaces produced at $56 \mathrm{~m} / \mathrm{s}$ do no present significant differences in the $R_{z}$ values when compared to those machined at $44 \mathrm{~m} / \mathrm{s}$ cutting speed, as the cutting distance is increasing. 


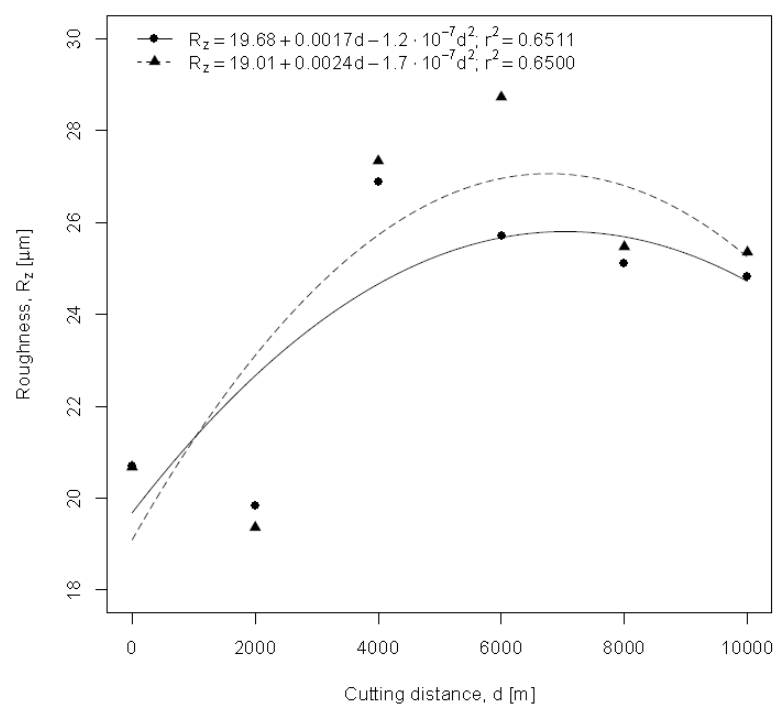

Figure 2. Effect of cutting distance (d) on surface roughness ( $\mathrm{R}_{\mathrm{z}}$ ) during Pinus radiata wood machining, using two cutting speeds, $44 \mathrm{~m} / \mathrm{s}$ (solid line) and $56 \mathrm{~m} / \mathrm{s}$ (dotted line), both at a feed speed of $38 \mathrm{~m} / \mathrm{min}$.

On the other hand, figure 3 shows the cutting distance effect on the wettability of the new surfaces. It can be observed that the wetting behaviour of the surfaces in function of cutting distance is similar for both cutting speed conditions $(44 \mathrm{~m} / \mathrm{s}$ and $56 \mathrm{~m} / \mathrm{s})$ i.e., contact angle tendency curves decreased from 0 meters of cutting distance, and then increased along with the cutting distance.

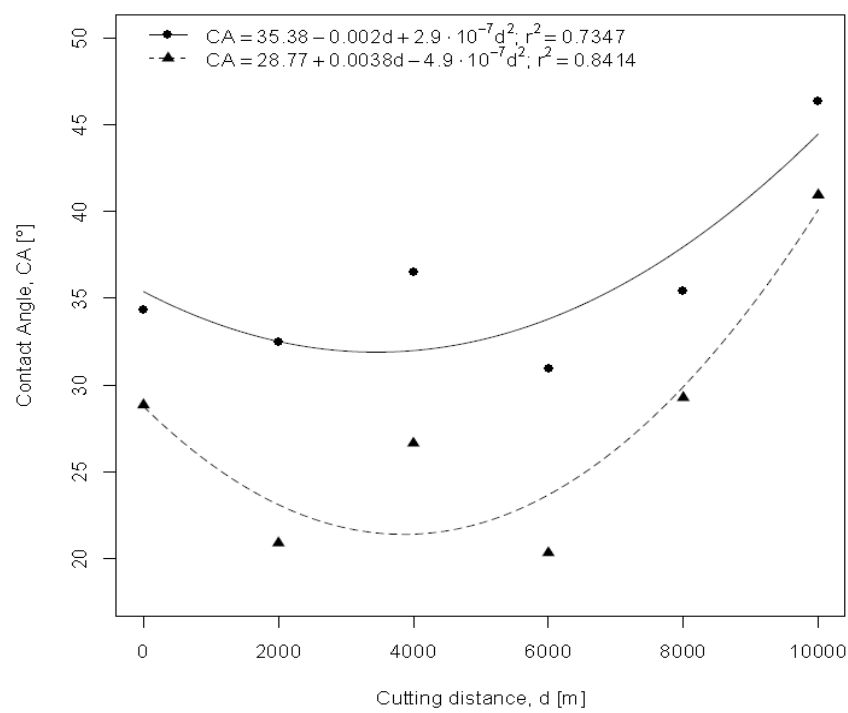

Figure 3. Effect of cutting distance (d) on contact angle CA during Pinus radiata wood machining, using two cutting speed $44 \mathrm{~m} / \mathrm{s}$ (solid line) and $56 \mathrm{~m} / \mathrm{s}$ (dotted line) both at the same feed speed, $38 \mathrm{~m} / \mathrm{min}$. 
When roughness and wettability are associated (Figure 2 and 3), it can be observed that similar contact angles are produced at 0 meters and at 7500 meters approximately of cutting distance. However, the $R_{z}$ values at these distances are different. Furthermore, over 8000 meters, the contact angle values become higher than those previously reached. Moreover, the contact angle achieved at 10000 meters is the highest, which indicates that the lowest wetting of the entire study has been attained.

On the other hand, and as a way to avoid moving the knives and keep the original calibration of the cutting tool, knife molds using silicone without removing the knives were made. However, this technique to measure wear resulted difficult and finally inadequate. Only the total average accumulated wear of 3,5 $\mu \mathrm{m}$ at 10000 meters was properly obtained from a removed knife at the end of the experiment. This wear on the cutting tool associated to the cutting distance, ultimately affects the behavior of roughness as well the wettability characteristics of the surface, as is shows by figure 2 and 3 .

In this study, Pinus radiata samples, machined using a three hydro centred mounting cutter-heads of 6 knives (HSS $6 \% \mathrm{~W}$ ) and a rake angle of $15^{\circ}$ each, the behaviour of roughness and wettability was evaluated. This is discussed below.

River et al. (1991), explains that the type of machining and conditions during machining affect the crack path and the type of surface. At microscopic level, there are three types of fracture: transwall, intrawall and intercellular. A longitudinal transwall crack passes through the cell wall and across the cell lumen, a longitudinal intrawall crack travels within the cell wall and around the lumen and an intercellular crack among cells. Probably, in this study the high contact angles at the initial meters of cutting distance, can be explained because transwall fracture occur due to the sharpness of the cutting tool. In this type of fracture the predominant surface is the lumen wall, it is coated with a layer of protoplasmic materials (warty layer) and it does not contribute to the wetting. As the cutting distance increased ( 0 to 6000 meters), the tool wear led to an increase in the roughness, as well as, a decrease in the contact angle. Rough surfaces may promote desiccation or overpenetration (Follrich 2010). Moreover, de Moura and Hernández (2007), found that better wetting properties are associated with higher surface roughness. This improvement in wetting is explained by intrawall crack.

Liquids are able to flow and penetrate the cracks and crevices of a rough surface, when this happens, the liquid adheres to the surface and is said to wet the surface (River et al. 1991). According to Borgin (1971), this type of fracture expose the S-1/S-2 region, these surfaces are highly polar with cellulose- and hemicellulose-rich of hydroxyl units available for wetting. Finally, River et al. (1991), indicates that once the cutting tool has accumulated more wear, the cell walls are compressed forming a smoother and even less porous surface than that formed with a sharp tool. This explains the behaviour of roughness and contact angle from 6000 to 10000 meters, where roughness begins to lower while contact angle begins to increase, indicating the lowest surface wettability.

The results suggest that further investigation on surface quality must be improved by adding a more detailed monitoring about changes on substrate anatomy and its chemistry, as well as, cutting tool microgeometry variation as is proposed by Keturakis and Juodeikiene (2007), during tool wear progression.

\section{CONCLUSIONS}

From this study it is possible to conclude that a wide spectrum of cutting distance allows an accurate evaluation of surface roughness and wettability behavior. These characteristics appear to vary in function of the cutting distance, and could be associated with the wear of the cutting tool, which seems to determine how a wood machined surface is wetted. Since cutting distance indicates similar contact angles for different roughness values, the interaction between both surface characteristics needs further study. 


\section{ACKNOWLEDGEMENTS}

The authors would like to thank the Research and Development Department (DID) and the Faculty of Forest Science and Natural Resources of the Austral University of Chile, as well as the National Commission for Scientific and Technological Research CONICYT, particularly the FONDECYT program, which financed the development of this research through the project FONDECYT No. 1120347.

\section{REFERENCES}

Aguilera, A.; Muñoz, H. 2011. Rugosidad superficial y potencia de corte en el cepillado de Acacia melanoxylon y Sequoia sempervirens. Maderas-Ciencia y tecnología 13(1): 19-28.

Aknouche, H.; Outahyon, A.; Nouveau, C.; Marchal, R.; Zerizer, A.; Butaud, J.C. 2009. Tool wear effect on cutting forces: In routing process of Aleppo pine wood. Journal of Materials Processing Technology 209:2918-2922.

Baysal, E.; Degirmentepe, S.; Simsek, H. 2014. Some surface properties of thermally modified scots pine after artificial weathering. Maderas-Ciencia y tecnología 16(3): 355-364.

Borgin, K. 1971. The cohesive failure of wood studied with the scanning electron microscope. $J$ Microsc 94(1): 1-11.

De Moura, G.; de Figueiredo, J.; de Moura, L.F.; Nolasco, A.; de Carvalho A.; Garcia, R. 2014. Surface roughness of heat treated Eucalyptus grandis wood. Maderas-Ciencia y tecnología $16(1): 3-12$.

De Moura, L.F.; Hernández, R.E. 2007. Characteristics of sugar maple wood surfaces machined with the fixed-oblique knife pressure-bar cutting system. Wood Sci Technol 41: 17-29.

Follrich, J.; Vay, O.; Veigel, S.; Müller, U. 2010. Bond strength of end-grain joints and its dependence on surface roughness and adhesive spread. J Wood Sci 56: 429-434.

Gilewicz, A.; Warcholinski, B.; Myslinskia, P.; Szymanskib, W. 2010. Anti-wear multilayer coatings based on chromium nitride for wood machining tools. Wear (270): 32-38.

Itaya, S.; Tsuchiya, A. 2003. Development of $\mathrm{CrN}$ coated tool to create smooth surface of solid wood aiming to mit sanding process in furniture production. In: Proceeding of the $16^{\text {th }}$ International Wood Machining Seminar, Matsue, Japan, pp.74-81.

Keturakis, G.; Juodeikiene, I. 2007. Investigation of Milled Wood Surface Roughness. Materials Science (Medžiagotyra) 13(1): 47-51.

Kilic, M.; Hiziroglu, S.; Burdurlu, E. 2006. Effect of machining on surface roughness of wood. Building and Environment 41:1074-1078.

Malkocoglu, A. 2007. Machining properties and surface roughness of various wood species planed in different conditions. Building and Environment 42: 2562-2567.

River, B.H.; Vick, C.B.; Gillespie, R.H. 1991. Wood as an adherend. Treatise on adhesion and adhesives. volume 7. New York: Marcel Dekker, Inc., 1991: 230 pp.

Thoma, H.; Peri, L.; Lato, E. 2015. Evaluation of wood surface roughness depending on species characteristics. Maderas-Ciencia y tecnología 17(2): 285-292. 